\title{
Studi Review Sistematis: Aplikasi Teori Disonansi Kognitif dan Upaya Reduksinya pada Perokok Remaja
}

\author{
Alexandra Tatgyana Suatan ${ }^{1}$, Irwansyah ${ }^{1}$ \\ ${ }^{1}$ Universitas Indonesia \\ Jl. Margonda Raya, Pondok Cina, Kecamatan Beji, Kota Depok, Jawa Barat 16424 \\ E-mail: ${ }^{1}$ alexandra.tatgyana01@ui.ac.id, ${ }^{1}$ irwansyah09@ui.ac.id
}

Received: Januari 2021; Accepted: April 2021; Published: Juni 2021

\begin{abstract}
Everyone agrees that smoking has a negative impact on health, including adolescents. The prevalence of adolescent smoking, which is still high, higher than the target of the Rencana Pembangunan Jangka Menengah Nasional (RPJMN), is a problem that has not been resolved from 2013 to the present. This problem solving difficulty is also driven by one of the elements of communication that occurs in adolescent smokers, namely cognitive dissonance. Cognitive dissonance is a feeling of discomfort experienced by a person when cognitive elements in him collide or are inconsistent. Adolescent smokers with cognitive dissonance are faced with the fact that smoking is harmful to health, but their behavior is inconsistent with this knowledge. The efforts made by teenagers to reduce discomfort are carried out in various ways. This study discusses two ways or concepts used by adolescent smokers to reduce cognitive dissonance that occurs using a systematic review method of previous literatures. The first concept is compensatory health belief $(\mathrm{CHB})$ and self-exempting belief.
\end{abstract}

Keywords: cognitive dissonance; adolescent smoker; tobacco use.

\begin{abstract}
Abstrak
Semua orang setuju bahwa perilaku merokok memberikan dampak yang negatif bagi kesehatan, termasuk remaja. Prevalensi perokok remaja yang masih tinggi, lebih tinggi daripada target Rencana Pembangunan Jangka Menengah Nasional (RPJMN) merupakan sebuah masalah yang belum dapat dipecahkan dari tahun 2013 hingga kini. Kesulitan pemecahan masalah ini juga didorong oleh salah satu elemen komunikasi yang terjadi dalam diri remaja perokok yakni disonansi kognitif. Disonansi kognitif adalah perasaan tidak nyaman yang dialami seseorang saat elemen-elemen kognitif dalam dirinya bertabrakan atau tidak konsisten. Remaja perokok yang mengalami disonansi kognitif dihadapkan dengan kenyataan pengetahuan di mana merokok berbahaya bagi kesehatan, tetapi perilaku mereka tidak konsisten terhadap pengetahuan tersebut. Upaya yang dilakukan para remaja untuk mereduksi ketidaknyamanan dilakukan dengan berbagai cara. Penelitian ini membahas dua cara atau konsep yang dilakukan oleh remaja perokok untuk mereduksi disonansi kognitif yang terjadi dengan menggunakan metode review sistematis terhadap literatur-literatur terdahulu. Konsep yang pertama adalah compensatory health belief $(\mathrm{CHB})$ dan self-exempting belief.
\end{abstract}

Kata Kunci: disonansi kognitif; perokok remaja; penggunaan tembakau

doi: https://doi.org/10.51544/jlmk.v5i1.1556

(C) 2021 Jurnal Lensa Mutiara Komunikasi. This is an open access article under the CC BY-SA license

Website: http://e-journal.sari-mutiara.ac.id/index.php/JLMI/

http://e-journal.sari-mutiara.ac.id 


\section{PENDAHULUAN}

Tidak ada orang yang memungkiri bahwa rokok memberikan efek yang negatif bagi tubuh, tetapi perilaku merokok orang Indonesia menunjukkan kejadian yang 'fenomenal'. Maksudnya, meskipun dampak negatif rokok sudah diketahui, tetapi jumlah dan prevalensi perokok di Indonesia semakin bertambah dan usia pertama kali merokok semakin muda.

Berdasarkan data dari Laporan Riset Kesehatan Dasar (Riskesdas) 2018 Nasional (Badan Penelitian dan Pengembangan Kesehatan, 2018), prevalensi nasional perokok tahun 2018 adalah $28,8 \%$. Selanjutnya, terkait proporsi merokok pada penduduk berusia lebih dari 10 tahun, sebesar $24,3 \%$ penduduk adalah perokok setiap hari dan 4,6\% penduduk adalah perokok kadang-kadang. Lebih lanjut lagi, rata-rata konsumsi rokok yang dikonsumsi oleh penduduk berusia 10-14 tahun adalah sebanyak 7 batang per hari dan penduduk berusia 15-19 tahun adalah sebanyak 10 batang per hari. Angka ini sudah mendekati angka rata-rata konsumsi rokok nasional yang adalah 13 batang per hari. Jika ditinjau dari sudut pandang proporsi umur pertama kali merokok tiap hari, sebanyak $0,9 \%$ penduduk merokok pertama kali di usia 5-9 tahun, sebanyak 10,6\% penduduk merokok pertama kali di usia 10-14 tahun, dan sebanyak 48,2\% penduduk merokok pertama kali di usia 48,2\%. Laporan ini menunjukkan bahwa lebih dari $50 \%$ penduduk yang merokok memulai perilaku merokoknya di usia anak dan remaja (5-18 tahun). Data ini didukung pula oleh hasil penelitian yang dilakukan oleh Lembaga Menanggulangi Masalah Merokok yang menyatakan bahwa perokok usia anak mulai merokok pada usia 9 tahun (Republika, 1998).

Secara khusus, berdasarkan Rencana Pembangunan Jangka Menengah Nasional (RPJMN) tahun 2019, prevalensi merokok pada populasi usia 10-18 tahun diharapkan dapat menyentuh angka 5,4\%. Akan tetapi pada kenyataannya, berdasarkan data dari Riskesdas tahun 2013, prevalensi merokok pada populasi 10-18 tahun adalah sebesar 7,2\%. Angka ini berada di atas target RPJMN 2019. Selain itu, berdasarkan data dari Survei Indikator Kesehatan Nasional (Sirkesnas) 2016 dan Riskesdas 2018, prevalensi merokok pada populasi usia 10-18 tahun adalah $8,8 \%$ dan $9,1 \%$. Hal ini menunjukkan adanya peningkatan prevalensi dan menyebabkan target RPJMN 2019 belum dapat terlaksana.

Meningkatnya jumlah perokok usia remaja diikuti dengan bertambah banyaknya orang yang memahami bahwa merokok berbahaya bagi kesehatan. Hal ini adalah hasil intervensi promosi kesehatan yang dilakukan selama bertahun-tahun oleh berbagai lembaga yang menyampaikan informasi tentang risiko kesehatan terkait merokok (Schreuders, Krooneman, Putte, \& Kunst, 2018). Menurut Halpern-Felsher dkk (2004), peningkatan pengetahuan individu tentang merokok berkontribusi untuk mencegah atau menghentikan seseorang dari kebiasaan merokok. Hal ini sejalan dengan teori perilaku model kepercayaan kesehatan (health belief model).

Bagaimana perokok menghadapi pertanyaan mengenai pengetahuan bahwa mereka terlibat dalam perilaku tidak sehat dan berpotensi mengalami penurunan kondisi kesehatan (perbedaan dua elemen kognitif, yakni perilaku dan pengetahuan) sering dibahas dalam penelitian-penelitian terdahulu. Literatur berikut ini menunjukkan bahwa perokok - dan bukan perokok yang berniat untuk merokok di kemudian hari (Halpern-Felsher, Biehl, Kropp, \& Rubinstein, 2004) - terus terlibat dalam proses rasionalisasi elemen kognitif akibat disonansi kognitif (perbedaan dua atau lebih elemen kognitif) yang terjadi (Borland et al., 2009), yang akhirnya membuat mereka mengurangi persepsi tentang risiko kesehatan akibat merokok (Weinstein, Marcus, \& Moser, 2005).

Menurut Laventhal dan Clearly (dalan Cahyani, 1995), terdapat berbagai macam cara untuk mereduksi disonansi kognitif yang terjadi, salah satunya adalah rasionalisasi salah satu 
elemen kognitif, yaitu keyakinan. Rasionalisasi keyakinan merupakan mekanisme psikologis yang terjadi di dalam diri manusia untuk mengurangi persepsi kerentanan terhadap bahaya yang dijadikan motivasi kunci manusia untuk mengubah perilakunya (Borland et al., 2009). Rasionalisasi keyakinan akan menghasilkan bias optimisme yang berfungsi untuk mengurangi disonansi kognitif (Weinstein, 1988). Akan tetapi, tidak seperti keyakinan berbasis pengalaman, keyakinan yang dirasionalisasi tidak dilandaskan pada realitas sehingga menyebabkan ketidakstabilan. Hal ini sejalan dengan pertanyaan Oakes et al. (2004) mengenai apakah rasionalisasi keyakinan akan menjadi penghambat utama seseorang untuk berhenti merokok atau hanya pertahanan kenyamanan semu yang akan hilang jika disonansi kognitif yang terjadi dapat direduksi dengan cara berhenti merokok.

Menurut identifikasi rasionalisasi keyakinan yang terjadi di atas, upaya intervensi kesehatan yang dilakukan untuk perokok, khususnya perokok remaja seharusnya tidak hanya memberikan informasi mengenai risiko kesehatan saja, tetapi memberikan perlakuan yang mumpuni yang dapat mencegah para perokok untuk terlibat dalam proses kognitif berupa rasionalisasi yang berujung kepada meremehkan risiko kesehatan itu sendiri. Berdasarkan latar belakang ini, penelitian ini akan membahas mengenai "Bagaimana teori disonansi kognitif terjadi pada perokok usia remaja?". Penelitian ini diharapkan dapat menjadi acuan bagi orangtua dan petugas kesehatan (terapis) untuk memahami fenomena disonansi kognitif yang terjadi pada perokok usia remaja sehingga dapat memberikan treatment atau perawatan dan perlakukan yang tepat untuk menanggulangi masalah ini secara komprehensif. Selain itu, diharapkan tulisan ini dapat menjadi acuan bagi pemerintah daerah dan pusat dalam memproduksi alat-alat komunikasi publik terkait larangan merokok pada anak usia remaja dengan pesan yang efektif dan menarik.

\section{TINJAUAN LITERATUR}

\section{Perilaku Merokok dan Faktor Penyebab Merokok di Usia Remaja}

Berdasarkan data yang disajikan di bagian pendahuluan dapat disimpulkan bahwa perilaku merokok dimulai saat masa kanak-kanak dan remaja. Dengan makin berkembangnya teknologi dan akses informasi, banyak anak dan remaja yang juga mengetahui bahaya dari merokok namun tidak menghindari perilaku tersebut. Menurut Gatchel (1989), krisis aspek psikososial yang dialami remaja saat berkembang dan mencari jati diri merupakan salah satu pemicu perilaku merokok. Hal ini merupakan 'kompensasi' atas adanya ketidaksesuaian antara perkembangan fisik yang sudah matang dengan perkembangan psikis dan sosial yang belum matang. Selanjutnya, menurut Brigham (1991), perilaku merokok pada usia remaja merupakan simbol. Maksudnya, merokok adalah simbol dari kematangan, kekuatan, kejantanan, dan pemicu daya tarik kepada lawan jenis.

Terdapat empat tahapan yang membuat seorang perokok akhirnya memutuskan untuk merokok. Pertama adalah tahap preparatory yang berujung kepada timbulnya minat terhadap perilaku merokok. Pada tahap ini, calon perokok mendapatkan gambaran menyenangkan tentang rokok dari hasil bertanya ataupun pencarian sendiri. Selanjutnya adalah tahap initiation atau tahap perintisan perilaku merokok yang akan membuat calon perokok memilih akan melanjutkan untuk memulai merokok atau tidak. Tahap ketiga adalah becoming a smoker. Seseorang dikatakan mempunyai kecenderungan menjadi perokok aktif adalah jika sudah mengonsumsi empat batang rokok per hari. Tahap terakhir adalah maintainance of smoking. Pada tahap ini, perilaku merokok adalah bagian dari kebiasaan (self-regulating), di mana perokok tersebut merokok untuk mendapatkan efek fisiologis yang menyenangkan. Sebelum menjadi perokok, 
seorang remaja akan bereksperimen dengan rokok. Dengan demikian, mereka dapat merasakan efek positif dari merokok (Radtke, Scholz, Keller, Knauper, \& Hornung, 2011).

Menurut Komasari dan Helmi (2000), perilaku merokok adalah perilaku yang dipelajari, maksudnya adalah seseorang yang mempelajari tentang rokok di masa kanak-kanaknya biasanya memutuskan untuk mulai merokok di usia remaja. Proses belajar didapat secara vertikal, yaitu dari sikap orangtua yang cenderung tidak melarang, dan horizontal, yaitu dari lingkungan. Akan tetapi, proses belajar juga terjadi secara internal, yaitu perilaku coba-coba yang memungkinkan calon perokok mendapat kepuasan yang diterima setelah merokok.

\section{Disonansi Kognitif}

Sebelum proses kognitif disebut sebagai penyebab terjadinya berbagai perilaku dalam diri manusia, di awal abad ke-20, istilah behaviorisme (faktor eksternal/rangsangan langsung memberikan efek terhadap perilaku) adalah yang paling sering digunakan untuk meneliti perilaku seseorang. Akan tetapi, di pertengahan abad ke-20, para psikolog mulai mendebatkan mengenai pendekatan kognitif atau faktor internal untuk memahami perilaku seseorang, daripada hanya berfokus kepada faktor eksternal saja (Dainton \& Zelley, 2018). Runes (1984) dalam Dainton dan Zelley (2018) menyatakan bahwa para psikolog di pertengahan abad ke-20 berpendapat proses mental yang terjadi dalam diri seseorang untuk memproses rangsangan demi menghasilkan efek tertentu perlu diperhatikan. Proses mental inilah yang disebut sebagai kognitif yang mencakup proses mengurangi, mengelaborasi, mengubah, dan menyimpan rangsangan.

Salah satu teori kognitif adalah Teori Disonansi Kognitif. Teori komunikasi dalam diri ini digagas oleh Leon Festinger pada tahun 1951. Dalam buku Theories of Human Communication, konsep teori disonansi kognitif terdiri dari dua hal, yaitu kognitif dan disonansi. Kognitif maksudnya elemen kognitif yang terdiri sikap, persepsi, pengetahuan, dan keyakinan. Sementara itu, disonansi maksudnya adalah konflik atau inkonsistensi atau tidak konsisten (Littlejohn, Karen, \& Oetzel, 2017). Gagasan dari teori ini adalah setiap orang memiliki atau membawa elemen-elemen kognitif, di mana setiap elemen tidak terisolasi, melainkan berhubungan satu sama lain. Hubungan yang terjadi dibagi menjadi 3, yakni hubungan yang tidak relevan, hubungan yang relevan dan saling memperkuat atau konsisten (konsonan), dan hubungan yang relevan dan saling bertabrakan atau tidak konsisten (disonan) (Littlejohn et al., 2017 dan Dainton dan Zelley, 2018). Menurut Festinger, ketika seseorang memiliki dua elemen kognitif yang berhubungan atau relevan tetapi tidak konsisten maka akan terjadi disonansi atau ketidaknyamanan.

Besarnya disonansi atau rasa tidak nyaman akibat inkonsistensi bergantung kepada beberapa hal, yaitu derajat kepentingan yang menunjukkan anggapan pentingnya suatu masalah, rasio disonansi yang menunjukan jumlah disonansi atau ketidaknyamanan yang dialami, dan kemampuan seseorang untuk merasionalisasi atau membenarkan yang menunjukkan alasan yang digunakan seseorang untuk menjelaskan mengapa inkonsistensi terjadi (Dainton \& Zelley, 2018).

Asumsi dasar teori disonansi kognitif adalah proses komunikasi yang terjadi dalam kehidupan seseorang membawa berbagai elemen kognitif yang saling berhubungan. Ketika dua elemen kognitif yang relevan mengalami ketidakkonsistenan, maka akan terjadi disonansi atau rasa tidak nyaman. Ketidakkonsistenan ini memotivasi seseorang untuk mengatasi disonansi yang terjadi dengan mengubah atau menyesuaikan beberapa bagian dari sistem kognitif (Littlejohn et al., 2017). Lebih lanjut Littlejohn et al. (2017) menyatakan ada empat cara untuk 
mengatasi atau mereduksi disonansi yang terjadi, yaitu dengan merasionalisasi elemen kognitif yang mengalami disonan, menambah elemen kognitif baru, melihat elemen penyebab disonansi sebagai hal yang kurang penting dibanding elemen kognitif yang lainnya, dan mengubah perilaku.

\section{Disonansi Kognitif dan Perilaku Merokok usia Remaja}

Menurut teori Festinger, pengalaman tidak menyenangkan sebagai akibat dari disonansi kognitif kemungkinan besar dialami perokok karena perilaku mereka bertentangan dengan fakta yang mereka dengan mengenai dampak merokok bagi kesehatan. Festinger (1957) juga memberikan hipotesis bahwa besarnya disonansi yang terjadi berfungsi sebagai tekanan yang besar bagi perokok untuk mereduksi disonansi yang terjadi. Oleh karena itu, orang akan beranggapan bahwa disonansi yang dialami perokok dipengaruhi oleh jumlah rokok per hari yang dihisap, maksudnya mereka yang merokok lebih banyak akan mengalami ketidakkonsistenan yang lebih besar.

Sebelum menjadi perokok, seorang remaja akan bereksperimen dengan rokok. Akan tetapi, secara bersamaan, mereka mungkin akan mengingat nasihat orangtua mereka untuk berhenti merokok atau mungkin mengalami efek negatif dari perilaku merokok tersebut. Perasaan ini muncul karena adanya konflik antara keingan untuk merokok dengan keinginan untuk hidup sehat atau menaati nasehat orangtua dengan menjaga kesehatan diri sendiri (Radtke et al., 2011).

Lebih lanjut, intervensi berupa informasi dampak merokok merupakan paparan yang akan dihindari oleh perokok. Intervensi atau paparan semacam ini, menurut teori Festinger akan menciptakan ketegangan yang tidak nyaman dalam diri perokok, di mana sebagian keteganan ini dihilangkan dengan membuat berbagai bentuk penyangkalan. Festinger (1957) menyatakan bahwa seorang perokok mungkin mengubah pengetahuannya tentang dampak merokok. Maksudnya adalah perokok mungkin saja akhirnya percaya bahwa merokok tidak merusak tubuhnya atau perokok mungkin memperoleh 'pengetahuan' yang menunjukkan efek positif dari merokok sehingga efek bahaya dari merokok dapat diabaikan begitu saja (Festinger, 1957).

Intervensi kesehatan merupakan salah satu cara untuk membuat perokok mengalami disonansi kognitif. Akan tetapi, memberikan intervensi yang tepat dan dapat mencegah para perokok untuk terlibat dalam proses kognitif berupa rasionalisasi yang berujung kepada meremehkan risiko kesehatan itu sendiri perlu dilakukan. Hal ini didukung oleh studi Fotuhi dkk di tahun 2011 yang menyebutkan bahwa pencegahan terhadap rasionalisasi perokok akan akan memotivasi mereka untuk berhenti merokok karena jika jalur reduksi disonansi berupa rasionalisasi ini diputus, maka satu-satunya cara yang tersisa bagi perokok untuk mengurangi disonansi yang terjadi adalah dengan mengubah perilaku (Fotuhi et al., 2011).

Salah satu alasan mengapa perokok termotivasi untuk mengurangi disonansi kognitif yang terjadi di dalam dirinya adalah karena konsistensi kognitif yang dihasilkan dari usaha mereduksi tersebut bermanfaat secara psikologis untuk meningkatkan kesehatan mental dan mempertahankan pandangan positif terhadap diri sendiri (Steele, 1988 dan Taylor, 1988 dalam Fotuhi et al., 2011). Namun, konsekuensi yang tidak disengaja dari mendukung keyakinan promerokok adalah perokok mungkin secara tidak sadar mengurangi kebutuhan psikologis mereka untuk mengubah perilaku. Hal ini didukung dengan beberapa penelitian terdahulu yang menemukan bahwa dukungan yang tinggi terhadap keyakinan pro-merokok berpengaruh terhadap niat untuk berhenti merokok yang rendah (Chapman, Wong, \& Smith, 1993). 
Jika dibandingkan dengan orang dewasa, anak remaja memiliki kecenderungan yang kuat untuk merasionalisasi perilaku merokoknya. (Schreuders et al., 2018). Beberapa literatur menunjukkan bahwa remaja dapat menggunakan berbagai rasionalisasi. Mereka mungkin akan percaya bahwa perilaku merokok dapat diimbangi dengan melakukan perilaku hidup sehat seperti makan sehat dan olahraga teratur (Radtke et al., 2011), mereka akan mengabaikan konsekuensi kesehatan akibat merokok, dan merokok tidak seburuk perilaku berisiko lainnya. Hal-hal ini berkaitan dengan compensatory health behaviour atau perilaku kesehatan kompensasi, di mana para remaja akan mengandalkan strategi kompensasi kognitif seperti 'perilaku merokok lebih sehat daripada makan makanan berlemak. Strategi kompensasi ini dilakukan untuk meminimalkan risiko kesehatan yang dirasakan akibat merokok.

\section{METODE PENELITIAN}

Penelitian ini dilaksanakan dengan metode review sistematis dengan mengikuti tahapan penelitian yang benar. Tahapan review sistematis pada penelitian ini dilakukan dengan beberapa langkah, yaitu menentukan pertanyaan penelitian, melakukan pencarian awal untuk memvalidasi ide, membuat kriteria inklusi dan eksklusi, membuat strategi pencarian, melakukan pencarian pada lokasi data-base yang dipilih, melakukan proses sortir pertama dengan membaca judul dan abstrak, melakukan proses sortir kedua dengan mengunduh dan membaca full-text, dan menulis manuskrip.

Penelitian ini dilaksanakan pada bulan November 2020 di kota Depok. Pencarian artikel ilmiah yang berhubungan dengan topik dan pertanyaan penelitian dilakukan dengan menggunakan kata kunci adolescent, smoker, cognitive dissonance, dan Indonesia di lokasi data-base PubMed. Akan tetapi, hasil yang keluar adalah nihil sehingga kata kunci Indonesia dihapus dan pencarian dilakukan dengan tiga kata kunci lainnya.

Adapun kriteria inklusi pada penelitian ini adalah artikel harus memuat kata kunci adolescent smoker dan cognitive dissonance, artikel terbatas pada sampel berusia 13-18 tahun, topik penelitian dibatasi pada disonansi kognitif yang terjadi pada perokok usia remaja, penelitian harus dilakukan pada perilaku merokok tembakau, artikel dipublikasikan setelah tahun 2000, dan artikel harus dituliskan dalam bahasa Inggris atau Indonesia. Kriteria eksklusi pada penelitian ini adalah sampel di luar usia 13-18 tahun, penelitian dilakukan pada perilaku merokok selain tembakau (mariyuana, ganja, dan vape), artikel dipublikasikan sebelum tahun 2000, dan artikel tidak ditulis dalam bahasa Inggris atau Indonesia.

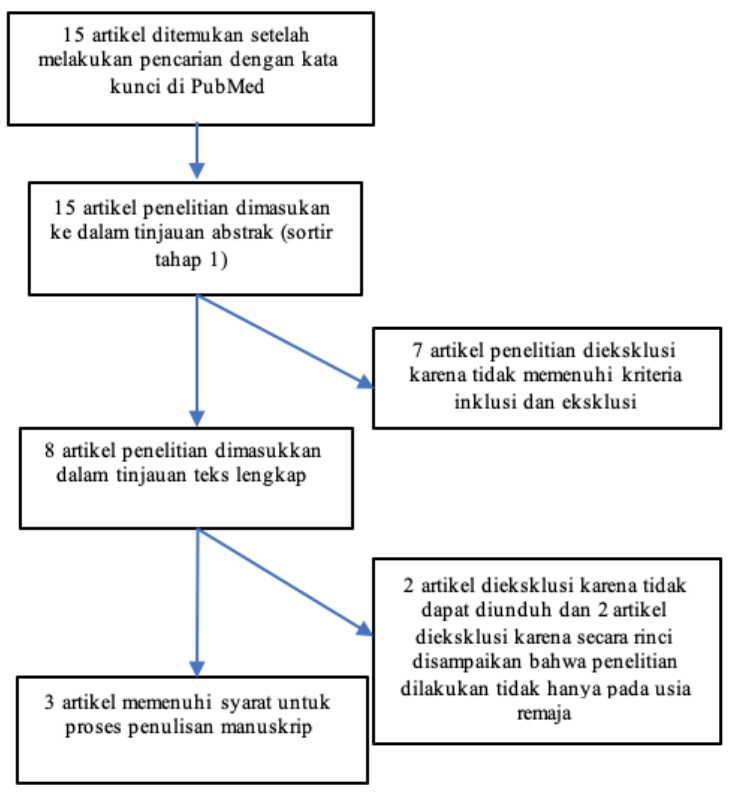

Gambar 1. Diagram Prosedur Pemilihan Artikel 


\section{HASIL DAN PEMBAHASAN}

Berdasarkan pencarian menggunakan tiga kata kunci, maka terdapat 15 artikel yang berhasil ditemukan. Selanjutnya, pembacaan judul dan abstrak dari 15 artikel tersebut dilakukan untuk melakukan proses sortir yang pertama dan didapati sebanyak 8 artikel tidak memenuhi kriteria inklusi dan eksklusi yang sudah dirancang. Selanjutnya proses sortir tahap kedua dilakukan dengan membaca full-text atau teks lengkap dari 7 artikel yang tersisa. Hasilnya adalah sebanyak 2 artikel tidak dapat digunakan karena teks lengkap tidak dapat diunduh dan sebanyak 2 artikel tidak dapat digunakan karena di bagian metode penelitian disampaikan bahwa penelitian tersebut dilakukan di beberapa golongan usia, yakni 9-12 tahun, 13-18 tahun, dan mahasiswa yang sudah tidak berada di kategori usia remaja. Gambar 1 menunjukkan prosedur pemilihan artikel yang telah dilakukan.

Artikel penelitian pertama berjudul Smoking-specific compensatory health beliefs and the readiness to stop smoking in adolescents. Penelitian ini dilakukan tahun 2011 di Swiss terhadap 676 responden dan bertujuan untuk mengembangkan skala compensatory health behaviour (CHB) perokok di kalangan remaja. CHB didefinisikan sebagai keyakinan bahwa konsekuensi negatif dari perilaku tidak sehat dapat dikompensasi dengan melakukan beberapa perilaku sehat lainnya (Radtke et al., 2011). Variabel tersebut penting diukur untuk memberikan informasi lebih lanjut mengenai perilaku remaja dalam memberikan kompensasi sebagai bentuk dari reduksi disonansi kognitif yang terjadi ketika merokok. Pada penelitian ini, Radtke et al. menyediakan kuesioner yang dibagikan kepada 676 remaja dari 56 kelas. Setiap responden diminta untuk mengerjakan kuesioner selama 1 jam pelajaran (45 menit). Dari hasil kuesioner didapatkan bahwa sebanyak 276 responden adalah perokok aktif dan 113 responden adalah perokok sesekali. Seluruh data yang dikumpulkan di analisis dengan menggunakan metode regresi hierarki.

Radtke et al. (2011) menambahkan satu variable terkait strategi reduksi disonansi dengan menambahkan 4 poin pernyataan yang berfungsi sebagai rasionalisasi bagi perokok dalam keadaan disonansi yang diukur dengan menggunakan skala Likert 5 poin. Contoh pernyataan pada variabel ini adalah 'banyak orang tua yang merokok hampir seumur hidupnya, namun tetap terlihat sehat' atau 'terlalu banyak perhatian diberikan kepada dampak berbahaya dari merokok'. Selain variable strategi reduksi disonansi, Radtke et al. (2011) juga menambahkan variabel kesiapan berhenti merokok yang dimanifestasi ke dalam pertanyaan kuesioner dan hasilnya diukur dengan menggunakan Tahapan Perubahan yang diadopsi dari Prochaska, DiClemente, dan Norcross (1992). Responden dapat mengukur kesiapan mereka untuk berhenti merokok dengan menggunakan skala 'dalam 30 hari kedepan', 'dalam 6 bulan', 'dalam 1 tahun', dan 'dalam 2 tahun'. Hasilnya adalah korelasi yang positif ditemukan antara CHB terkait perilaku merokok dengan strategi pengurangan disonansi. Selain itu, perokok remaja yang memiliki tingkat CHB yang tinggi memiliki kesiapan yang lebih rendah untuk berhenti merokok.

Artikel penelitian yang kedua berjudul Perceived risks and benefits of smoking: differences among adolescents with different smoking experiences and intentions. Penelitian ini dilakukan oleh Helpern-Felsher et al. pada tahun 2004 di Amerika Serikat terhadap 395 responden remaja yang duduk di bangku sekolah kelas Sembilan. Responden berasal dari beberapa etnis berbeda seperti Asia, Latin, penduduk pulai Pasifik, Afrika Amerika, Amerika asli (orang Indian), dan lain-lain. Pengukurang yang dilakukan dalam penelitian ini adalah pengukuran demografi, seperti usia, tingkat pendidikan, jenis kelamin, etnis, dan pendidikan terakhir orangtua (ibu), perkiraan peluang risiko dan manfaat dari merokok, dan perilaku merokok dan niat untuk merokok. 
Pengukuran Helpern-Felsher et al. (2004) untuk melihat perkiraan peluang risiko dan manfaat dari merokok dilakukan melalui tiga risiko sosial, tujuh risiko terkait kesehatan tubuh, dan empat risiko kecanduan. Risiko sosial itu adalah terlibat masalah, bau badan seperti bau asbak, dan memiliki teman yang tidak suka dengan perokok. Sementara risiko terkait kesehatan tubuh diantara lain adalah batuk parah, sulit bernapas, pilek yang sangat parah, bau mulut, kanker paru, serangan jantung, dan kerutan di wajah. Untuk risiko kecanduan, diantaranya adalah dapat berhenti jika mau, menjadi kecanduan, akan merokok dalam lima tahun, dan berhenti merokok itu mudah. Selain risiko, dari penelitian di atas diukur pula tiga manfaat sosial, yaitu terlihat keren, menjadi lebih popular, dan terlihat lebih dewasa, dan dua manfaat fisik, yaitu merasa rileks atau lebih tenang dan lebih kurus.

Hasilnya, hipotesis penelitian ini terbukti, yaitu remaja atua responden yang telah merokok memberikan peluang lebih rendah terhadap risiko merokok (pada 10 dari 14 item risiko) dan memberikan peluang lebih tinggi terhadap manfaat merokok. Dari 5 item peluang manfaat, remaja yang telah merokok menilai peluang mereka untuk menerima manfaat dari merokok secara signifikan lebih tinggi dari remaja yang tidak merokok pada tiga manfaat sosial dan satu manfaat fisik (lebih rileks).

Artikel penelitian ketiga berjudul Boy Smokers' Rationalisations for Engaging in Potentially Fatal Behaviour: In-Depth Interviews in The Netherlands. Penelitian ini dilakukan di tahun 2018 oleh Michael Schreuders dkk di Belanda terhadap 16 remaja Belanda yang tinggal di kota Amsterdam. Penelitian dilakukan dengan metode interview semi terstruktur. Metode ini dilakukan karena memungkinkan Schreuders untuk menguraikan secara menyeluruh bagaimana laki-laki berusia 16-17 tahun merasionalkan pandangan mereka mengenai risiko kesehatan yang ditimbulkan sebagai akibat merokok dan perilaku merokok yang mereka lakukan. Selain itu, melalui metode ini, dapat dipastikan bahwa tiap orang akan memberikan jawaban yang original, bukan jawaban yang ikut-ikutan. Setelah wawancara, hasil wawancara akan ditranskripsikan secara verbatim untuk dianalisis lebih lanjut. Analisis difokuskan kepada penemuan rasionalisasi berulang yang menjelaskan bagaimana pengetahuan mereka bahwa rokok berbahaya dan fakta bahwa mereka merokok.

Hasil dari penelitian yang dilakukan oleh Schreuders, et al. (2018) adalah terdapat tiga rasionalisasi berulang yang menunjukkan bagaimana perokok laki-laki usia remaja perbedaan antara pengetahuan tentang bahaya merokok, rasionalisasi 1 adalah konsekuensi akibat rokok diremehkan, dapat dikompensasikan, dan sebanding dengan manfaat merokok, rasionalisasi 2 adalah perilaku merokok hanya terjadi pada usia remaja sehingga tubuh dapat pulih dari kerusakan yang ditimbulkan, dan rasionalisasi 3 adalah konsekuensi kesehatan dapat dicegah selama ada kontrol terhadap jumlah dan frekuensi merokok.

Pada rasionalisasi 1, remaja laki-laki memperhatikan bahwa merokok tidak baik bagi kesehatan dan memberikan dampak yang langsung. Satu orang menyatakan bahwa setelah merokok tidak dapat menyelesaikan satu pertandingan penuh sepak bola. Hal ini didukung juga oleh pernyataan remaja lain yang adalah seorang penari yang merasa bahwa merokok mempengaruhi kekuatan gerakannya. Selain itu, remaja lain juga menyatakan bahwa jika ia merokok sebelum bersepeda, maka ia akan bersepeda lebih lambat. Hanya sedikit laki-laki remaja yang berpendapat bahwa konsekuensi kesehatan langsung membuat mereka ingin berhenti merokok.

Selanjutnya pada rasionalisasi 2, remaja laki-laki berpendapat bahwa kerusakan yang disebabkan oleh merokok merupakan akibat dari jumlah rokok yang banyak dan frekuensi merokok yang sering. Mereka juga berasumsi bahwa jike mereka merokok dalam waktu yang 
singkat tidak akan mengakibatkan kerusakan permanen dari tubuhnya dan dapat pulih. Mereka yang baru merokok dalam kurun waktu sekitar empat tahun akan menganggap orang yang sudah merokok seumur hidupnya akan terkena kanker paru. Oleh sebab itu, mereka akan berhenti sekarang agar tidak mengalami konsekuensi yang sama.

Selanjutnya adalah rasionalisasi 3, remaja laki-laki berpendapat bahwa mereka dapat mencegah konsekuensi kesehatan akibat merokok selama mereka tetap mengontrol jumlah dan frekuensi merokok. Mereka akan mengusahakan berbagai macam taktik untuk merasionalisasi perilakunya agar tidak perlu berhenti dengan cara membatasi jumlah rokok yang dikonsumsi perhari, tidak merokok untuk jangka waktu tertentu saja, atau tidak merokok saat bersama keluarga. Keberhasilan para remaja untuk tidak merokok dalam jangka waktu tertentu merupakan konfirmasi bahwa mereka mampu berhenti total di kemudian hari.

Pada penelitian Radtke et al. (2011) CHB didefinisikan sebagai keyakinan bahwa konsekuensi negatif dari perilaku tidak sehat dapat dikompensasi dengan melakukan beberapa perilaku sehat lainnya (Radtke et al., 2011). Hal ini adalah salah satu upaya untuk mereduksi disonansi dengan cara menambah elemen kognitif baru. Maksudnya, daripada menolak keinginan untuk merokok atau mengevaluasi kembali keyakinan responden perokok, mereka akan membenarkan perilakunya. Disonansi yang terjadi di awal memutuskan untuk merokok dapat melemah dari waktu ke waktu dan menyebabkan kebutuhan untuk mengkompensasi perilaku tidak sehat memudar. Hal ini menyebabkan orang yang ingin berhenti merokok akan dihalangi oleh CHB, karena mereka dapat merokok tanpa merasa bersalah (disonansi melemah) atas dampak negatif kesehatannya (Rabiau, Knauper, \& Miquelon, 2006).

Terhadap penelitian Helpern-Felsher et al. (2004) mengenai peluang risiko dan manfaat merokok yang dialami perokok remaja, faktanya, penelitian menunjukkan bahwa remaja perokok mungkin kurang khawatir tentang risiko jangka panjang dari merokok sebagian karena mereka percaya bahwa mereka dapat berhenti merokok dengan mudah dan kapan saja (Arnett, 2000). Hal ini sejalan dengan konsep self-exempting belief yang pertama, yaitu bulletproof belief (keyakinan antipeluru) di mana seseorang berpikir bahwa risiko penurunan kesehatan akibat merokok tidak berlaku untuk mereka. Hasil penelitian Helpern-Felsher et al. (2004) juga menunjukkan bahwa penting untuk disadari bahwa remaja tidak semata-mata mempertimbangkan konsekuensi kesehatan terkait merokok tetapi juga menemukan konsekuensi sosial serta manfaat menjadi penting.

Banyak literatur menunjukkan keseragaman dengan hasil penelitian dari Schreuders, et al. (2018), di mana perokok remaja terlibat dalam proses rasionalisasi kognitif untuk mengurangi disonansi yang terjadi untuk menghadapi fakta pengetahuan bahwa mereka terlibat dalam perilaku yang fatal. Hal ini sejalan dengan penelitian lanjutan dan hipotesis mengenai teori Disonansi Kognitif Festinger (1957) yang menyatakan bahwa perokok mungkin akan mengubah pengetahuannya tentang dampak merokok. Mereka akan percaya bahwa merokok tidak merusak tubuh bahkan memberikan efek yang positif.

\section{KESIMPULAN}

Perokok remaja pasti mengalami disonansi kognitif ketika merokok, seperti pengabaian nasihat orangtua dan pengetahuan akan bahaya merokok terhadap kesehatan. Akan tetapi, ketiga penelitian secara konsisten menyebutkan bahwa disonansi kognitif akan direduksi oleh remaja perokok dengan berbagai cara seperti compensatory health behaviour atau strategi memberikan kompensasi kognitif dan rasionalisasi yang sejalan dengan konsep self-exempting belief yang digunakan untuk menurunkan persepsi mereka terkait kerentanan personal sebagai dampak dari 
perilaku merokok. Jika kita mampu untuk mengatasi perilaku kompensasi dan rasionalisasi pada perokok remaja ini, ada kemungkinan terjadinya peningkatan persepsi remaja perokok tentang kerentanan diri sendiri terhadap risiko kesehatan akibat merokok.

\section{DAFTAR PUSTAKA}

Arnett, Jeffrey Jensen. "Optimistic Bias in Adolescent and Adult Smokers and Nonsmokers." 25 (2000). https://doi.org/10.1016/s0306-4603(99)00072-6.

Badan Penelitian dan Pengembangan Kesehatan. Riset Kesehatan Dasar 2018. Kementerian Kesehatan RI (Jakata: 2018).

Borland, Ron, Hua-Hie Yong, James Balmford, Geoffrey T. Fong, Mark P. Zanna, and Gerard Hastings. "Do Risk-Minimizing Beliefs About Smoking Inhibit Quitting? Findings from the International Tobacco Control (Itc) Four-Country Survey." Elsevier Inc. (2009). https://doi.org/10.1016/j.ypmed.2009.06.015.

Brigham, C.J. Social Psychology. Boston: Harper Collins Publisher, Inc., 1991.

Chapman, Simon, Wai Leng Wong, and Wayne Smith. "Self-Exempting Beliefs About Smoking and Health:Differences between Smokers and Ex-Smokers." American Journal of Public Health 83 (1993).

Dainton, Marianne, and Elaine D Zelley. Applying Communication Theory for Professional Life. California: Sage Publisher, 2018.

Festinger, L. A Theory of Cognitive Dissonance. Illinois: Row and Peterson, 1957.

Fotuhi, Omid, Geoffrey T Fong, Mark P Zanna, Ron Borland, Hua-Hie Yong, and K Michael Cummings. "Patterns of Cognitive Dissonance-Reducing Beliefs among Smokers: A Longitudinal Analysis from the International Tobacco Control (Itc) Four Country Survey." British Medical Journal: Tobacco Control (2011). https://doi.org/10.1136/tobaccocontrol-2011-050139.

Gatchel, R.J. An Introduction to Health Psychology. New York: Mc Graw-Hill Book Company, 1989.

Halpern-Felsher, Bonnie L., Michael Biehl, Rhonda Y. Kropp, and Mark L. Rubinstein. "Perceived Risks and Benefits of Smoking: Differences among Adolescents with Different Smoking Experiences and Intentions." The Institute For Cancer Prevention and Elsevier Inc (2004). https://doi.org/10.1016/j.ypmed.2004.02.017.

Komasari, Dian, and Avin Fadilla Helmi. "Faktor-Faktor Penyebab Perilaku Merokok Pada Remaja." Jurnal Psikologi (2000).

Littlejohn, Stephen, A Foss Karen, and John G Oetzel. Theories of Human Communication (11th Edition). Boston: McGraw Hill, 2017.

Oakes, Wendy, Simon Chapman, Ron Borland, James Balmford, and Lisa Troter. "“Bulletproof Skeptics in Life's Jungle': Which Self-Exempting Beliefs About Smoking Most Predict Lack of Progression Towards Quitting?". The Institute For Cancer Prevention and Elsevier Inc. (2004). https://doi.org/10.1016/j.ypmed.2004.03.001.

Rabiau, M, B Knauper, and P Miquelon. "The External Quest for Optimal Balance between Maximizing Pleasure and Minimizing Harm: The Compensatory Health Beliefs Model." British Journal of Health Psychology (2006). https://doi.org/10.1093/her/cyp032.

Radtke, Theda, Urte Scholz, Roger Keller, Barbel Knauper, and Rainer Hornung. "SmokingSpecific Compensatory Health Beliefs and the Readiness to Stop Smoking in 
Adolescents." British Journal of Health Psychology (2011). https://doi.org/10.1348/2044-8287.002001.

Republika. 1998. Lebih Tiga Juta Meninggal karena Tembakau dalam Setahun. Harian Republika. 30 Oktober 1998.

Schreuders, Michael, Nikha T. Krooneman, Bas van den Putte, and Anton E. Kunst. "Boy Smokers' Rationalisations for Engaging in Potentially Fatal Behaviour: In-Depth Interviews in the Netherlands." International Journal of Environmental Research and Public Health (2018). https://doi.org/10.3390/ijerph15040767.

Weinstein, N D. "The Precaution Adoption Process." Health Psychology (1988). https://doi.org/10.1037//0278-6133.7.4.355.

Weinstein, N D, S E Marcus, and R P Moser. "Smokers' Unrealistic Optimism About Their Risk." British Medical Journal: Tobacco Control (2005). https://doi.org/10.1136/tc.2004.008375. 